\title{
Efforts and Changes Around School Libraries in Sweden Today
}

\author{
Fredrik Ernerot \\ School Library West, Gothenburg, Sweden
}

\begin{abstract}
As the 2017 IASL conference theme will be "Learning without borders" it is interesting to focus on how the school library, as well as the school librarian, will have to adopt the field - to establish and develop the field as a whole. By describing the whole field, with a perspective taken from the Swedish school library, from the present situation 2016/2017 and even further than that, there will be a contribution of useful material and methods - inspirational to the work and progress for school libraries/school librarians. Three specific subjects will be presented during the lecture - mainly to create a sustainable knowledge on school libraries as a learning tool in school - with a special focus on the political and structural efforts/changes taking place in Sweden today. The three specific subjects are: the Swedish National Agency for Education, The national school library group of Sweden (NSG), School Library West (SBV).
\end{abstract}

\section{Keywords: Sweden, School Library, School Development, Information Literacy, National Agency of Education}

\section{INTRODUCTION}

Sweden (9.9 million people) has 290 municipalities, 290 public library systems, and about 4000 school libraries. Public libraries and school libraries are financed by local authorities. The municipal council makes decisions in matters concerning libraries, compulsory school, upper secondary school and preschool. Sweden has a long tradition of local municipal autonomy. Local authorities are independent bodies, which are free to make their own decisions within certain limits. Compulsory schooling in Sweden is from first to ninth grade. A preschool year from six years of age is a part of Swedish schools, but not compulsory for children.

"When local authorities are given new tasks, their right to municipal autonomy must be taken into account. This sort of situation may arise when an area in which local authorities have previously provided services on a voluntary basis, such as libraries, is brought under regulation", the government says. This is why legislation often is not detailed. School directors and principals are the ones who have mandate from the local authorities to decide how the money is spent and how the schools are going to follow the law. The Swedish schools, principals and municipalities must now manage school libraries.

The National Library of Sweden $(K B)$ has the responsibility to coordinate support for all libraries. Within the public library sector, there are 20 county and regional libraries with the assignment to encourage cooperation and development through projects such as reading promotion, development of library service for different target groups, and lifelong learning. According to the Library Act, regional libraries do not have mandate to provide for school libraries, but they can cooperate with school libraries in their regions.

\section{THE SWEDISH NATIONAL AGENCY FOR EDUCATION A Summary and a Definition of the School Library}

The Swedish National Agency for Education has a valuable department working with school library issues. The Agency has a reference group for school library matters. An Agency officer manages a discussion list for school librarians, provides informative journalistic web articles on school library best 
practice, and a website called Check the source about information literacy, critical awareness, use of social media and web tools for daily school work. In the guidelines from the National Schools Inspectorate, a definition of school library from the Agency is quoted:

A shared and well-regulated resource comprised of media and information, which is put at the disposal of the pupils and teachers with the help of competent staff. The school library is a part of the school's teaching activities with the task of supporting the pupils' learning. The school library can therefore be regarded partly as a material resource which is part of a school's teaching aids and other tools, and partly as a function which actively contributes to the development of

\section{Background} knowledge and is responsible for certain services (Translated in Jensinger, 2013).

The Swedish National Agency for Education is one of the three big national authorities for schools, belonging to the Ministry of Education and Research. The other two governmental authorities are The Schools Inspectorate and The National Agency for Special Needs Education and Schools.

\section{The Swedish Education System 1}

In Sweden there are almost 11000 schools (pre schools included). 1.5 million pupils (21\% of the population). There are about 4000 school libraries connected to compulsory and upper secondary schools (6078 school). According to statistics from 2010 67\% of the Swedish schools units have a school library. One third of the Swedish pupils have no access to a school library. Statistics 2016 shows similar figures as mentioned above.

\section{The Swedish Education System 2}

The Swedish school system is decentralized since 1991, which means that the municipalities/ local schools authorities are responsible for and finance the schools, even the independent schools. Independent schools include $9 \%$ of the pupils in compulsory and $17 \%$ in upper secondary school. The national goals for Swedish schools are set by Swedish Parliament and Government in The Education Act, Curricula, Course Syllabi and Program Goals. All these documents (apart from the Education Act) are being renewed and revised during 2017. To put some weight behind the words here, the Swedish minister of schools Jan Björklund quoted: The Swedish School System is "undergoing the biggest school reform since 1842."

\section{The New Education Act}

A proposition about a new Education Act was left for political decision in 2010. It was approved, and was set to start in autumn 2011. One important reform within the Education Act is that Swedish pupils are guaranteed access to school libraries. This does not mean that every rural school with 50 pupils have to employ a librarian, but as school authority you have to include school library - the pupils need for information and reading possibilities in your plan for school activities. Being part of the Education Art also means that the school libraries are included in the inspection of schools (made every third year by The Schools Inspectorate), something that has not been reality earlier.

\section{The National Agency And School Libraries}

The goal for the Agency is to steer and support schools through different steering documents. The Agency was head of big national school library projects during the years 2000-2004 as well as 2007, including competence development for school librarians. The Agency also publishes research about school library and information literacy, as well as school library articles on the Agency's website. There is also a discussion list for school librarians with around 1000 subscribers, as well as wikis for teachers and librarians. The reference group for school libraries at the Agency started in 2009. There were discussions about strategic issues and even printed/digital materials were produced through the group. Later on the group focused on a referral for the new Education Act, as well as the definition on school library (referred earlier in the text).

\section{News from the Swedish National Agency for Education}

- With a start in autumn 2016 principals have the possibility to search for contribution, when it comes to reinforce staff at the school library. The Agency administrates the governmental funding for school librarians. 1, 6 million dollar 2016. 3, 2 million dollar 2017. An evaluation will take place 2017. 
- All Swedish curriculas are being revised during 2017 with the aim to strengthen the writings about digital competence. The schools can decide to start working with the revised versions from July 1, 2017

- School library in the revised curriculas: It's the principles responsibility that the school library is being used to support teaching, empower the pupils language abilities and their digital competence. This is an important sentence and a tool and argument for staffing the school library with an educated school librarian.

- The Agency also offers training initiative, where school librarians are a special target group. A readingas well as a media literacy staking will be offered for both school librarians and teachers.

- A new reference group of school librarians (40-50 members) is formed. As an effect of that a wide scale of conferences, meetings and projects are organized. Everything is connected to the above skills development.

- The National Agency of Education is since 2016 member of a network consisting of eight national authorities, three of them school authorities. The main issue for the group is school libraries. The group supports the work with the national library strategy with some external environment monitoring. For example: In 2016 the network published an overview about Swedish school libraries. There is also a discussion about producing a leaflet addressing school providers.

- There will be a new strategy set for the Swedish Library ready in 2019. The school library will be a main field for the work with the strategy.

\section{THE NATIONAL SCHOOL LIBRARY GROUP OF SWEDEN (NSG)}

The National School Library Group vision is a Sweden where staffed school libraries are a natural and integral part of the schools work.

In Sweden one network stands out, maybe unique in its structure, consisting of stakeholders interested in school library development. The network is the brain behind the writings about school libraries included in the new Education Act. The strength of the network is that it is composed, not only by school librarians, but also by representatives from all school areas, such as teachers, school heads, writers and public libraries.

The National School Library Group was founded in the 1990s by authors (writers of books). The authors reacted to municipalities cutting down libraries, often situated in schools. The curriculum left the responsibility of libraries to the head of each school. The authors wrote debate articles in newspapers and supported work for defending libraries. Eventually the NSG group grew and became an expert group fighting for and encouraging the development of school libraries for the benefit of student achievement and interest in reading.

Until 2016 the group has had more than 20 member associations, collaborating to achieve strong outcomes across the school library sector as a whole. Some of them are NGOs, trade unions, regional associations, as well as The Swedish Library Association. Government departments have also been represented as well as The Swedish National Library. NSG acts to alert responsible officers and politicians of the role and mission of the school library in the school's educational work. The target groups for NSG advocacy work may be principals, teacher training institutions, universities, government agencies and other stakeholders.

From 2016 the organisation for NSG has changed, to more of an advocacy group around the keyissues (12 organisations). Now there is also one specific group for the Government apartments (8 apartments). The reason for this is to get a more effective NSG group, where reality in a closer way meets the field of subject. NSG also urge to be more effective in the working/meeting-process, where less often tend to be more, so to speak.

One important advocacy task for NSG is to select the Swedish School Library of the Year. The award consists of a work of art and an author visit for the students. In the year when the school gets the award, the school librarian often gives lectures and receives visits from other schools.

NSG, like many of its members, also publish leaflets, organizes conferences (e.g., yearly at School Fair and Book \& Library Fair) and constitutes an important reference group for policy and law. Arranging appointments with politicians and important national officials with connection to education is 
another way that NSG works. Over the years, the group members have called on several ministers of education and met with politicians who have shown special interest in culture and libraries. The different associations within NSG eventually understood the school library advocacy problems better and maybe understood each other better. They learnt how to talk to officials, and they had an influence on the school library issue becoming known and discussed in parliament and in the education department of government.

When the new Education Act was passed in 2011, NSG and the Swedish Library Association conducted a massive information campaign to make the regulations known to all principals in Sweden. The campaign content was taken from the criteria developed by The National Schools Inspectorate for their coming inspections. The Inspectorate states that the following requirements must be met for students to be considered to have access to school libraries:

1. Students have access to a school library on their own school unit's premises or at a reasonable distance from the school that makes it possible to continuously use the library as a part of students' education in order to contribute to achieving the objectives.

2. The library includes books, non-fiction and fiction, information technology and other media.

3. The library is adapted to the pupils' needs in terms of promoting language development and stimulating reading. (Translated in Jensinger, 2013).

Finally, updated in 2016/2017 - The main goals for The National School Library Group:

- Make sure decision makers pay attention on the importance of well-functioning school libraries for students learning and development.

- Demonstrate school libraries impact on students reading development and media/information literacy.

- $\quad$ Strengthen stakeholders at all levels in their efforts for staffed school libraries.

- Spreading knowledge of good practices, including the price Swedish School Library of the Year.

- Promoting debate about the role of the school library.

- $\quad$ Spreading knowledge of relevant research and current policy documents.

\section{THE SWEDISH LIBRARY ASSOCIATIONS}

There are three regional associations of school librarians in Sweden: East, West and South, all of them located in each geographical region of the country.

The first regional association south started up in 1998. Then a few years later followed the association east, and in 2008 the association west was born. The main issues for the associations are: promoting school library matters, operating lobbying activities, arrange seminars and activities at national fairs, and pay attention to the working method where librarians and teachers get connected as a working unit in school.

The associations also produce supporting materials for school libraries. For example: Guidelines for school libraries, debate articles and interviews with school librarians and folders.

The price "The School Librarian of the Year" has been a long running award in Sweden, promoted by the Swedish Writers Union. A price given to a school librarian, like The National School Library Groups price (see above), have been working in a quality way.

Since 2010 The Swedish Library Association has been the actor behind the price. Today two different prices (in the associations East and West) have replaced the price.

As noticed there are many similarities between the association's issues and The National School Library Group. There are several reasons for that, but one of the more central facts is that the associations from the beginning have been a representative part of the National School Library Group. Therefore much of the both parties thoughts, knowledge and information has been shared in both arenas. This is a strength that leads to success for both parties. Responsiveness and esteem for the field in a whole are the key tools here.

There are also clear differences between the both parties. The Associations are member-based groups. There is a board with several members, as well as a chairman. There is an annual meeting on every year basis, where the board is elected in a democratic way. Each member in the association has the 
right to vote. There is also a fee connected to the membership in the association. Compared to the National School Library Group this makes a major difference. This is important to understand, because out of the member's collective force of "free will", the work around school libraries gets connected to real ground - the reality and everyday life in an ordinary school.

\section{SCHOOL LIBRARY WEST (SBV)}

School Library West was established in 2008. For many years there was a desire for a network for school librarians in the region. When the decision was made - to start up an association, directly after one important meeting at the Book-fair in Gothenburg (major city in the region west), it was highly welcomed by many.

There were particularly two reasons for the establishment of a new association:

1. To take advantage of the facilities of Gothenburg as the major "city of fairs" in the region, as well as in the country and even abroad.

2. To put effort in the working method, where librarians and teachers get connected and cooperate as a working unit in school.

Louise Limbergs respected research were central. The results showed early on (1990) new tasks for school librarians:

- To teach critical use of information.

- To offer many sources for school work

- To cooperate with teachers to develop teaching towards analysing knowledge content instead of mediating sources.

Several more researchers made huge impact on the boards members. Especially the American researchers Dr Carol Kuhlthau and Dr Ross Todd. Researchers that later made it over to Sweden, invited to talk about their research and professional experiences, which has had such a great impact on the understanding of the complex field: school library teaching.

Out of this came the real start and work for School Library West. Five goals (mind-maps) were seen through the many suggestions that reached the board during this period:

- Acting to bring the school library into the future (Pedagogical \& Technical)

- Being a creating venue (Web, meetings, debates)

- Acting in a modern way (Web 2.0, promoting, marketing)

- Acting through crossover (Facing possibilities)

- Defend the regional touch (Create contact surfaces)

Among the amount of activities taking place, there are a few actions, connected to the goals of the association, worth some extra attention:

- Arrangements - conferences, lectures and meetings for school librarians and teachers.

- Operating lobbying activities, as well as meeting members of Sweden's school library associations, mainly at Book-fairs and Teach-meets.

- Managing the yearly "Malin Koldenius scholarship" award.

\section{Arrangements - Conferences, Lectures and Meetings for School Libraries and Teachers}

School Library West has from the start valued further training for school libraries and teachers, as an important part of the association's mission. As Gothenburg since a long time is the main centre for Sweden's biggest book- and library fair, School Library West have seen it as the home arena.

In 2010 the IFLA conference was arranged in Gothenburg. School Library West arranged an official Pre-conference around school libraries. The conference entitled "The future for school libraries in a national \& international perspective" ended up as an international arrangement with some of the most well known lecturer in the field for that time, such as: Dr. Ross Todd, Rutgers University, New Jersey, USA, Dr. Lesley Farmer, California State University, Long Beach, USA and Luisa Marquardt, University "Roma Tre", Rome, Italy. 
When the famous writer and former teacher Aidan Chambers toured Europe, School Library West booked him for two dates. Methods around literacy, as well as discussions around literature gave both librarians and teachers a good chance to extra guiding in their work. Many teachers went straight home to their schools and started working immediately with the methods.

Even after mentioned occasions, the association has arranged several more conferences and meetings around the school library field. Even around the area of research, published in Sweden. Dr. Louise Limberg was one of the key-speakers for a conference around a book facing the Swedish history of research. It was published in 2013, named The school Library roles in changing landscapes.

\section{Operating Lobbying Activities, as Well as Meeting Members of Sweden's Library} Associations, Mainly at Book-Fairs and Teach-Meets

One of the most important issues for the association is to be a communicative part around the field: school library. Through the years School Library West have made work at fairs, as well as meetings, arranging showcases especially for members from the associations. Delivering free-tickets, selling in memberships to both - single school librarians and corporations and sponsors.

For some years now School Library West and the book-publisher Nypon have been working together, with one common goal: more activities around reading and education in the school library. It has been a fruitful way of growing, both as a movement and as an association.

Except meeting and communicate with people, School Library West and Nypon print material, deliver information, informing about membership and helping customers with reading material.

School Library West also produce exclusive interviews while working at fairs and meetings. In depth conversations with key-persons in the field, on all levels - from authorities to single school librarians and teachers. The material are exposed on the official blog for School Library West. This way the association give the whole country a better knowledge around the situation for school library. Stakeholders of different kind are clear addresses for this type of production. So far the work has been declared as a success by the public.

\section{Managing the Yearly "Malin Koldenius Scholarship" Award}

One of the associations five goals concentrate on getting librarians and teachers connected as a working unit in school. The yearly scholar ship, in honour to School Library Wests founder of the award Malin Koldenius, state this work in a most practical way.

From the beginning Malin Koldenius, prolonged librarian and consultant at Region library in the western part of Sweden, thought of different ways to get a descent development, when it comes to teachers using school libraries as a place for education and knowledge.

Malin Koldenius instituted the scholarship at School Library Wests annual meeting. Along with the award itself, came also an amount of money donated to the association. Koldenius delivered the price herself, on stage at the great Bock-fair in Gothenburg. A lot of people showed up, as well as media and newspapers. The award was declared to a teacher using the school library in a creditable way.

When Malin Koldenius, after a time of sickness, suddenly passed away, the price was left in the association's service. Koldenius mentioned in her own will - that she wanted the award to be a part of School Library Wests work in the future. There for my task as the chairman of the association is to continue deliver the award, at an every year basis, at the Book-Fair in Gothenburg. In September this year it will be delivered for the eighth time.

\section{CONCLUSION}

The following subjects included in this paper are mainly presented as a platform for the upcoming lecture at IASL 2017 entitled: Learning without borders - Efforts and changes around school libraries in Sweden today. A deeper look into some of the issues described in this paper follows as a natural way of taking further steps down the road, so to speak.

The Swedish National Agency of Education 
The school law, as well as present statistics on the situation for school libraries in Sweden. More over exclusive information on the political and structural efforts around school libraries in Sweden today. The topics are:

1. A presentation of the work inside the reference group during 2016/2017, where meetings, conferences and discussions between teachers and libraries have been implemented.

2. Governmental economical investment on staff for Swedens wide scale of municipalities.

3. The recently started cooperation around the school library issue between eight national agencies.

The National School Library Group of Sweden (NSG)

A network of central organizations connected to school libraries in Sweden. Focus is mainly on NSG: as a lobbyist to stakeholders in Sweden, as well as an inspirational force to the development of school libraries in Sweden.

\section{School Library West (SBV)}

Focus is set on the associations work for the school library as an intellectual place for knowledge, rather than just a place for administration. Also on the efforts being done in getting the librarian and the teacher connected as a working unit in school.

\section{REFERENCES}

Barrett, Helle, \& Eriksson, Bibbi. (2013). A government mandate for school libraries in Sweden. Retrieved from http://www.ifla.org/node/7926

Hell, Maud. (2014). Collaboration for school library legislation and school library development in Sweden. Retrieved from http://www.ifla.org

Holmqvist, Anette. (2010). Today and tomorrow - The Swedish school libraries in a national perspective and context. Retrieved from http://www.skolverket.se

Jensinger, Edward. (2014). Headmaster's view of the school library. Scandinavian Library Quarterly, 46(1). Retrieved from http://slq.nu/?article=volume-46-no-1-2013-7

School Library West (SBV). (2008-2016). Retrieved from http://skolbibliotekvast.blogspot.se/

School Library West (SBV). (2008). Five goals (mind-maps). Retrieved from

http://skolbibliotekvast.blogspot.se/p/verksamhetside.html

The Swedish Library Associations. (2016). Retrieved from http://skolbibliotek.se

The Swedish Library Associations. (2016). Facebook. Retrieved from

http://www.facebook.com/Skolbibliotekse-252624871473192/

The National school library group of Sweden. (2016). Retrieved from https://skolbiblioteksgruppen.wordpress.com

The National school library group of Sweden. (2016). The main goal. Retrieved from

https://skolbiblioteksgruppen.wordpress.com/om-gruppen/ 